\title{
Attitudes regarding euthanasia among Wroclaw university students surveyed in 2011-2012
}

\author{
DOI: https://doi.org/10.5114/pq.2020.89814
}

\author{
Anna Maria Choińska', Ludwika Sadowska², Bożena Bartosik ${ }^{3}$, Ewa Gieysztor ${ }^{4}$, Artur Polczyk', \\ Henryk Filipowski ${ }^{5}$, Iwona Demczyszak ${ }^{6}$, Eleonora Mess ${ }^{7}$ \\ ${ }^{1}$ Department of Physiotherapy, Faculty of Health Sciences, Wroclaw Medical University, Wroclaw, Poland \\ ${ }^{2}$ Development Rehabilitation Laboratory, Faculty of Health Sciences, Wroclaw Medical University, Wroclaw, Poland \\ ${ }^{3}$ Faculty of Education, University of Lower Silesia, Wroclaw, Poland \\ ${ }^{4}$ Department of Clinical Bases of Physiotherapy, Faculty of Health Sciences, Wroclaw Medical University, Wroclaw, Poland \\ ${ }^{5}$ Department of Pathophysiology, Faculty of Medicine, Wroclaw Medical University, Wroclaw, Poland \\ ${ }^{6}$ Department of Rehabilitation, Faculty of Medicine, Wroclaw Medical University, Wroclaw, Poland \\ ${ }^{7}$ Department of Clinical Nursing, Faculty of Health Sciences, Wroclaw Medical University, Wroclaw, Poland
}

\section{Abstract}

Introduction. The research was conducted to measure the views held by students towards euthanasia.

Methods. The opinions were recorded by using a survey with 12 statements and 5-grade Likert scale responses. The research involved 376 students: 168 students of physiotherapy and 103 students of nursing and midwifery from the Wroclaw Medical University, and 105 pedagogy students from the University of Lower Silesia.

Results. Most respondents considered euthanasia (65\%) as an act of killing. The majority of students (around $90 \%$ from both universities) believed that the subject of death should not be removed from everyday life and that human death differed from that of an animal. Moreover, $63 \%$ considered death sacred and related it with hope for eternal life, although women were more willing to take part in hospice work than men.

Conclusions. In Poland, medical and education studies help develop attitudes of life protection from start to finish. The students of nursing and midwifery and of physiotherapy presented greater respect for life than students of education.

Key words: euthanasia, students' opinion, hospice

\section{Introduction}

The subject of euthanasia has been raised as a dispute for centuries in the society, typically among philosophers and those in the industry of medicine. The death of a human causes fear, therefore each way of recreating it or helping a person to die is difficult and controversial [1-5].

A long time ago, euthanasia was perceived as an art, as a way to die in peace with dignity, very often with the use of painkillers [6-8]. Here, we well tell apart medical acts of ending an ill and/or suffering patient's life from the morally justified result of ongoing treatments, the latter being too burdensome for both the patient and their relatives [9-11].

Nowadays, euthanasia is accepted in a number of places, to name just a few: Albania, the Netherlands, Luxembourg, Japan, various parts of Australia, Texas and Oregon in the USA, Germany, and Switzerland. In Poland, euthanasia is not allowed in any form or any situation. The International Code of Medical Ethics and the Church refuse to accept euthanasia in all circumstances [1-6, 12].

The reader of this paper can and should feel like a philosopher for a while. According to Krąpiec et al. [13], a philosopher, in the classical sense, also wants to explain what is given directly, experimentally, and thus the fact of the existence of many different objects. But the point of view from which they look at the existing reality is the existence itself, the very fact of the existence of the world, a man, anything and everything together. A philosopher's goal is to search for nonaccidental factors (the deepest causes) of anything, for example, here, of euthanasia. A philosopher asks questions about the world unknown in any other area of science: Why does a man, other beings, the whole world exist at all? Thanks to what, due to which factors (even if these were eternal) is the existence of the world of things and people in fact real? How can there really be something that does not exist?

The objective of this research was to examine the attitudes of students in Wroclaw universities towards euthanasia by using a questionnaire of 12 statements related to the subject.

\section{Subjects and methods}

\section{Participants}

The research involved a group of 376 students of 2 Wroclaw universities: Wroclaw Medical University, Faculty of Health Sciences (MU) and the University of Lower Silesia, Faculty of Education (ULS). The students were divided into 3 groups: $168 \mathrm{MU}$ students of physiotherapy (group 1), 103 MU students of nursing and midwifery (group 2), and 105 ULS students of education (group 3). The surveys took place in the universities in 2011 and 2012. The demographic characteristics of the groups is illustrated in Table 1.

Correspondence address: Ewa Gieysztor, Faculty of Health Sciences, Wroclaw Medical University, ul. Grunwaldzka 2, 50-355, Wrocław, Poland, e-mail: ewa.gieysztor@umed.wroc.pl 
Table 1. Demographic characteristics of the students taking part in the survey

\begin{tabular}{|c|c|c|c|c|c|}
\hline \multirow{2}{*}{\multicolumn{2}{|c|}{ Group }} & \multirow{3}{*}{$\begin{array}{c}\begin{array}{c}\text { Population } \\
n(\%)\end{array} \\
168(45)\end{array}$} & \multicolumn{2}{|c|}{$\begin{array}{c}\text { Gender } \\
n(\%)\end{array}$} & \multirow{3}{*}{$\begin{array}{l}\text { Age (years) } \\
24.1 \pm 3.6\end{array}$} \\
\hline & & & \multirow{2}{*}{$\begin{array}{c}\text { Female } \\
149(89)\end{array}$} & \multirow{2}{*}{$\begin{array}{c}\text { Male } \\
19(11)\end{array}$} & \\
\hline 1 & Physiotherapy, MU & & & & \\
\hline 2 & Nursing and midwifery, MU & $103(27)$ & $99(96)$ & $4(4)$ & $21.7 \pm 5.4$ \\
\hline 3 & Education, ULS & $105(28)$ & $80(76)$ & $25(24)$ & $27.8 \pm 9.1$ \\
\hline \multicolumn{2}{|c|}{ Total } & $376(100)$ & $328(87)$ & $48(13)$ & $24.5 \pm 6.5$ \\
\hline
\end{tabular}

MU - Wroclaw Medical University, ULS - University of Lower Silesia

\section{Measurements}

The authors' questionnaire containing statements about euthanasia was used to conduct the research. The statements were in planned in a specific order, so that the respondent could give an objective answer regardless of the responses provided earlier. The surveyed students were asked to read and understand 12 statements regarding euthanasia, putting a tick next to each using the given Likert scale. The Likert scale is the most commonly applied tool for measuring attitudes. The reason for that is probably the simplicity of the scale design. The scale can provide a response concerning the degree of acceptance of a given opinion. It consists of an odd number of responses, usually 5: (1) I strongly disagree with the statement; (2) I somewhat disagree with the statement; (3) I have no opinion; (4) I somewhat agree with the statement; (5) I strongly agree with the statement. The central response is as neutral as possible and the initial and final responses are as extreme as possible. Using the Likert scale allows to detect even small differences in attitudes that are examined. This specifically refers to attitudes towards unnatural death, which includes euthanasia or death in atypical circumstances, e.g. after a court sentence. If the measurements are obtained on an ordinal scale, the relations of the majority and minority can be considered, which allows for a comparative analysis [14, 15]. The applied questionnaire contained statements about euthanasia; these 12 features were marked with symbols (from $X_{1}$ to $X_{12}$ ) in their descriptions and scores as represented in Table 2 . The results of the students' answers are provided in Table 2 with respect to gender and field of study. The answers were evaluated and verified with the ANOVA method for statistical analysis of variables; the Statistica software (version 10) was applied. Statistical verification was performed with the chi $^{2}$ test, with the significance level of $p<0.05$, and Pearson's correlation coefficient significance level was $p<0.05$. The comparison of the results is shown in Table 3.

\section{Ethical approval}

The research related to human use has complied with all the relevant national regulations and institutional policies, has followed the tenets of the Declaration of Helsinki, and has been approved by the authors' institutional review board or an equivalent committee.

\section{Informed consent}

Informed consent has been obtained from all individuals included in this study.

\section{Results}

Table 2 presents the distribution of students, in both numbers and percentages, answering the 12 statements about euthanasia (diagnostic features $X_{1}-X_{12}$ ). Overall, $65 \%$ of the respondents agreed with the statement that euthanasia was killing a human (feature $\mathrm{X}_{2}$ ); $27 \%$ of the students did not agree with the statement, and $9 \%$ had no opinion on whether euthanasia was considered killing.

In the analysis of the opinions with regard to the university the respondents were attending, it is necessary to emphasize that the curriculum influenced their knowledge, shaping their opinions and attitudes, raising the conscious view that killing a human at the beginning or the end of life was a murder. The majority of the respondents agreed that euthanasia was killing a human (feature $\mathrm{X}_{2}$ ); this was stated by $72 \%$ of students in nursing and midwifery, $65 \%$ of students of physiotherapy, and $54 \%$ of those in education. The comparison made with the $\mathrm{chi}^{2}$ test showed that these differences were statistically significant.

There is a dispute about the controversial death penalty as a legal means of social justice for the most severe crimes against society. Half of the students $(52 \%)$ agreed that death penalty should be a legal punishment for the most severe crimes (feature $X_{3}$ ). A thorough analysis of the students' arguments suggests that their views on death penalty were connected with the curriculum they undertook: $55 \%$ of physiotherapy students (group 1), $49 \%$ of nursing and midwifery students (group 2), and $51 \%$ of education students (group 3 ) either agreed or strongly agreed that death penalty should be a legalized means of punishment for the most severe crimes, but the differences were statistically significant when comparing physiotherapy (group 1) with other students (groups 2 and 3 ).

When responding to the statement 'If I could participate in the hospice movement or otherwise help terminally ill people, I would' (feature $X_{5}$ ), $56 \%$ of the students stated that they would involve in this kind of work. Terminally ill people can count on help from $59 \%$ of physiotherapy students, $61 \%$ of nursing and midwifery students, and $45 \%$ of education students. There were no statistically significant differences among the groups. The only statistically significant difference was noticed in declaring the willingness to participate in hospice work between women (60\%) and men (32\%), with women showing greater empathy.

The statement regarding removing the subject of death from everyday life (feature $X_{6}$ ) gave results showing that $90 \%$ of students - $93 \%$ physiotherapy students, $96 \%$ nursing and midwifery students, and significantly fewer education students $(80 \%)$ - strongly did not agree with it. This score can be 
Table 2. Quantity of students' answers in the survey on euthanasia

\begin{tabular}{|c|c|c|c|c|c|c|c|c|c|c|c|c|c|c|}
\hline \multirow[t]{2}{*}{ Feature } & \multirow[t]{2}{*}{ Statement } & \multirow[t]{2}{*}{$\begin{array}{c}\text { Answer } \\
\text { to the question: } \\
\text { Do you agree } \\
\text { with the statement? }\end{array}$} & \multicolumn{2}{|c|}{$\begin{array}{l}\text { Students } \\
(n=376)\end{array}$} & \multicolumn{2}{|c|}{$\begin{array}{l}\text { Females } \\
(n=328)\end{array}$} & \multicolumn{2}{|c|}{$\begin{array}{l}\text { Males } \\
(n=48)\end{array}$} & \multicolumn{2}{|c|}{$\begin{array}{l}\text { Physio- } \\
\text { therapy, MU } \\
\text { (group 1) } \\
(n=168)\end{array}$} & \multicolumn{2}{|c|}{$\begin{array}{l}\text { Nursing } \\
\text { and } \\
\text { midwifery, } \\
\text { MU } \\
\text { (group 2) } \\
(n=103)\end{array}$} & \multicolumn{2}{|c|}{$\begin{array}{l}\text { Education, } \\
\qquad \text { ULS } \\
\text { (group 3) } \\
(n=105)\end{array}$} \\
\hline & & & $n$ & $\%$ & $n$ & $\%$ & $n$ & $\%$ & $n$ & $\%$ & $n$ & $\%$ & $n$ & $\%$ \\
\hline$X_{1}$ & $\begin{array}{l}\text { The American Civil Rights Union (ACRU) believes } \\
\text { that euthanasia, at the request of a person that } \\
\text { is terminally ill or handicapped, triggers a need } \\
\text { for the requested action (by withdrawing help } \\
\text { or actively causing death) by a third party. } \\
\text { According to ACRU, this type of death is a part } \\
\text { of the legal right to control one's own life }{ }^{\mathrm{b}, \mathrm{c}}\end{array}$ & $\begin{array}{l}1 \\
2 \\
3 \\
4 \\
5\end{array}$ & $\begin{array}{r}88 \\
34 \\
78 \\
65 \\
111\end{array}$ & $\begin{array}{r}23 \\
9 \\
21 \\
17 \\
30\end{array}$ & $\begin{array}{l}76 \\
30 \\
67 \\
59 \\
96\end{array}$ & $\begin{array}{r}23 \\
9 \\
20 \\
18 \\
29\end{array}$ & $\begin{array}{r}12 \\
4 \\
11 \\
6 \\
15\end{array}$ & $\begin{array}{r}25 \\
8 \\
23 \\
13 \\
31\end{array}$ & $\begin{array}{l}44 \\
14 \\
32 \\
22 \\
56\end{array}$ & $\begin{array}{r}26 \\
8 \\
19 \\
13 \\
33\end{array}$ & $\begin{array}{l}33 \\
15 \\
15 \\
19 \\
21\end{array}$ & $\begin{array}{l}32 \\
15 \\
15 \\
18 \\
20\end{array}$ & $\begin{array}{r}11 \\
5 \\
31 \\
24 \\
34\end{array}$ & $\begin{array}{r}10 \\
5 \\
30 \\
23 \\
32\end{array}$ \\
\hline$X_{3}$ & $\begin{array}{l}\text { Death penalty should be a legal punishment } \\
\text { for the most violent crimes }\end{array}$ & $\begin{array}{l}1 \\
2 \\
3 \\
4 \\
5\end{array}$ & $\begin{array}{r}122 \\
26 \\
32 \\
48 \\
148\end{array}$ & $\begin{array}{r}32 \\
7 \\
9 \\
13 \\
39\end{array}$ & $\begin{array}{r}107 \\
24 \\
27 \\
42 \\
128\end{array}$ & $\begin{array}{r}33 \\
7 \\
8 \\
13 \\
39\end{array}$ & $\begin{array}{r}15 \\
2 \\
5 \\
6 \\
20\end{array}$ & $\begin{array}{r}31 \\
4 \\
10 \\
13 \\
42\end{array}$ & $\begin{array}{r}62 \\
4 \\
10 \\
18 \\
74\end{array}$ & $\begin{array}{r}37 \\
2 \\
6 \\
11 \\
44\end{array}$ & $\begin{array}{r}31 \\
14 \\
8 \\
16 \\
34\end{array}$ & $\begin{array}{r}30 \\
14 \\
8 \\
16 \\
33\end{array}$ & $\begin{array}{r}29 \\
8 \\
14 \\
14 \\
40\end{array}$ & $\begin{array}{r}28 \\
8 \\
13 \\
13 \\
38\end{array}$ \\
\hline$X_{4}$ & $\begin{array}{l}\text { The knowledge of the physiology and pathology } \\
\text { processes of dying, as well as death, is not } \\
\text { relevant to our lives }\end{array}$ & $\begin{array}{l}1 \\
2 \\
3 \\
4 \\
5\end{array}$ & $\begin{array}{r}161 \\
43 \\
72 \\
38 \\
62 \\
\end{array}$ & $\begin{array}{l}43 \\
11 \\
19 \\
10 \\
16 \\
\end{array}$ & $\begin{array}{r}148 \\
39 \\
60 \\
32 \\
49 \\
\end{array}$ & $\begin{array}{l}45 \\
12 \\
18 \\
10 \\
15 \\
\end{array}$ & $\begin{array}{r}13 \\
4 \\
12 \\
6 \\
13 \\
\end{array}$ & $\begin{array}{r}27 \\
8 \\
25 \\
13 \\
27\end{array}$ & $\begin{array}{l}74 \\
16 \\
28 \\
15 \\
35\end{array}$ & $\begin{array}{r}44 \\
10 \\
17 \\
9 \\
21 \\
\end{array}$ & $\begin{array}{r}51 \\
10 \\
20 \\
9 \\
13 \\
\end{array}$ & $\begin{array}{r}50 \\
10 \\
19 \\
9 \\
13 \\
\end{array}$ & $\begin{array}{l}36 \\
17 \\
24 \\
14 \\
14\end{array}$ & $\begin{array}{l}34 \\
16 \\
23 \\
13 \\
13 \\
\end{array}$ \\
\hline$X_{5}$ & $\begin{array}{l}\text { If I could participate in the hospice movement } \\
\text { or otherwise help terminally ill people, I woulds }\end{array}$ & $\begin{array}{l}1 \\
2 \\
3 \\
4 \\
5 \\
\end{array}$ & $\begin{array}{r}52 \\
35 \\
79 \\
70 \\
140 \\
\end{array}$ & $\begin{array}{r}14 \\
9 \\
21 \\
19 \\
37 \\
\end{array}$ & $\begin{array}{r}41 \\
28 \\
64 \\
64 \\
131 \\
\end{array}$ & $\begin{array}{r}13 \\
9 \\
20 \\
20 \\
40 \\
\end{array}$ & $\begin{array}{r}11 \\
7 \\
15 \\
6 \\
9 \\
\end{array}$ & $\begin{array}{l}23 \\
15 \\
31 \\
13 \\
19 \\
\end{array}$ & $\begin{array}{l}26 \\
11 \\
32 \\
32 \\
67\end{array}$ & $\begin{array}{r}15 \\
7 \\
19 \\
19 \\
40 \\
\end{array}$ & $\begin{array}{r}7 \\
10 \\
23 \\
22 \\
41 \\
\end{array}$ & $\begin{array}{r}7 \\
10 \\
22 \\
21 \\
40 \\
\end{array}$ & $\begin{array}{l}19 \\
14 \\
24 \\
16 \\
32 \\
\end{array}$ & $\begin{array}{l}18 \\
13 \\
23 \\
15 \\
30 \\
\end{array}$ \\
\hline$X_{7}$ & $\begin{array}{l}\text { Focusing on the subject of death lowers one's } \\
\text { creative energy }\end{array}$ & $\begin{array}{l}1 \\
2 \\
3 \\
4 \\
5\end{array}$ & $\begin{array}{r}179 \\
62 \\
58 \\
37 \\
40 \\
\end{array}$ & $\begin{array}{l}48 \\
16 \\
15 \\
10 \\
11 \\
\end{array}$ & $\begin{array}{r}155 \\
57 \\
53 \\
31 \\
32 \\
\end{array}$ & $\begin{array}{r}47 \\
17 \\
16 \\
9 \\
10 \\
\end{array}$ & $\begin{array}{r}24 \\
5 \\
5 \\
6 \\
8 \\
\end{array}$ & $\begin{array}{l}50 \\
10 \\
10 \\
13 \\
17 \\
\end{array}$ & $\begin{array}{l}81 \\
24 \\
24 \\
15 \\
24 \\
\end{array}$ & $\begin{array}{r}48 \\
14 \\
14 \\
9 \\
14 \\
\end{array}$ & $\begin{array}{r}54 \\
20 \\
18 \\
5 \\
6 \\
\end{array}$ & $\begin{array}{r}52 \\
19 \\
17 \\
5 \\
6 \\
\end{array}$ & $\begin{array}{l}44 \\
18 \\
16 \\
17 \\
10 \\
\end{array}$ & $\begin{array}{l}42 \\
17 \\
15 \\
16 \\
10 \\
\end{array}$ \\
\hline$X_{8}$ & $\begin{array}{l}\text { The death of an animal is no different } \\
\text { from the death of a human being }{ }^{\mathrm{b}, \mathrm{c}}\end{array}$ & $\begin{array}{l}1 \\
2 \\
3 \\
4 \\
5\end{array}$ & $\begin{array}{r}191 \\
64 \\
50 \\
31 \\
40 \\
\end{array}$ & $\begin{array}{r}51 \\
17 \\
13 \\
8 \\
11\end{array}$ & $\begin{array}{r}166 \\
57 \\
45 \\
24 \\
36 \\
\end{array}$ & $\begin{array}{r}51 \\
17 \\
14 \\
7 \\
11 \\
\end{array}$ & $\begin{array}{r}25 \\
7 \\
5 \\
7 \\
4\end{array}$ & $\begin{array}{r}52 \\
15 \\
10 \\
15 \\
8\end{array}$ & $\begin{array}{l}92 \\
20 \\
22 \\
13 \\
21\end{array}$ & $\begin{array}{r}55 \\
12 \\
13 \\
8 \\
13 \\
\end{array}$ & $\begin{array}{r}65 \\
16 \\
9 \\
7 \\
6 \\
\end{array}$ & $\begin{array}{r}63 \\
16 \\
9 \\
7 \\
6\end{array}$ & $\begin{array}{l}34 \\
28 \\
19 \\
11 \\
13\end{array}$ & $\begin{array}{l}32 \\
27 \\
18 \\
10 \\
12 \\
\end{array}$ \\
\hline$X_{9}$ & $\begin{array}{l}\text { Efforts to extend the life of terminally ill people } \\
\text { have a significant social and economic impact }\end{array}$ & $\begin{array}{l}1 \\
2 \\
3 \\
4 \\
5\end{array}$ & $\begin{array}{r}72 \\
43 \\
81 \\
54 \\
126\end{array}$ & $\begin{array}{l}19 \\
11 \\
22 \\
14 \\
34 \\
\end{array}$ & $\begin{array}{r}64 \\
39 \\
72 \\
45 \\
108\end{array}$ & $\begin{array}{l}20 \\
12 \\
22 \\
14 \\
33\end{array}$ & $\begin{array}{r}8 \\
4 \\
9 \\
9 \\
18 \\
\end{array}$ & $\begin{array}{r}17 \\
8 \\
19 \\
19 \\
38 \\
\end{array}$ & $\begin{array}{l}24 \\
11 \\
37 \\
17 \\
79 \\
\end{array}$ & $\begin{array}{r}14 \\
7 \\
22 \\
10 \\
47\end{array}$ & $\begin{array}{l}24 \\
18 \\
14 \\
21 \\
26 \\
\end{array}$ & $\begin{array}{l}23 \\
17 \\
14 \\
20 \\
25\end{array}$ & $\begin{array}{l}24 \\
14 \\
30 \\
16 \\
21\end{array}$ & $\begin{array}{l}23 \\
13 \\
29 \\
15 \\
20 \\
\end{array}$ \\
\hline$X_{10}$ & $\begin{array}{l}\text { Taking care of a terminally ill person has } \\
\text { a positive effect on both the sick person } \\
\text { and the guardian }\end{array}$ & $\begin{array}{l}1 \\
2 \\
3 \\
4 \\
5\end{array}$ & $\begin{array}{r}24 \\
36 \\
52 \\
62 \\
202\end{array}$ & $\begin{array}{r}6 \\
10 \\
14 \\
16 \\
54\end{array}$ & $\begin{array}{r}21 \\
33 \\
40 \\
55 \\
179\end{array}$ & $\begin{array}{r}6 \\
10 \\
12 \\
17 \\
55\end{array}$ & $\begin{array}{r}3 \\
3 \\
12 \\
7 \\
23\end{array}$ & $\begin{array}{r}6 \\
6 \\
25 \\
15 \\
48\end{array}$ & $\begin{array}{l}17 \\
15 \\
23 \\
21 \\
92\end{array}$ & $\begin{array}{r}10 \\
9 \\
14 \\
13 \\
55\end{array}$ & $\begin{array}{r}4 \\
11 \\
9 \\
17 \\
62\end{array}$ & $\begin{array}{r}4 \\
11 \\
9 \\
17 \\
60\end{array}$ & $\begin{array}{r}3 \\
10 \\
20 \\
24 \\
48\end{array}$ & $\begin{array}{r}3 \\
10 \\
19 \\
23 \\
46\end{array}$ \\
\hline$X_{11}$ & $\begin{array}{l}\text { It is hard for me to imagine having any kind } \\
\text { of contact with a dying person }{ }^{\text {b }}\end{array}$ & $\begin{array}{l}1 \\
2 \\
3 \\
4 \\
5\end{array}$ & $\begin{array}{r}171 \\
54 \\
35 \\
38 \\
78\end{array}$ & $\begin{array}{r}45 \\
14 \\
9 \\
10 \\
21\end{array}$ & $\begin{array}{r}154 \\
48 \\
27 \\
32 \\
67\end{array}$ & $\begin{array}{r}47 \\
15 \\
8 \\
10 \\
20\end{array}$ & $\begin{array}{r}17 \\
6 \\
8 \\
6 \\
11\end{array}$ & $\begin{array}{l}35 \\
13 \\
17 \\
13 \\
23\end{array}$ & $\begin{array}{l}84 \\
21 \\
16 \\
16 \\
31\end{array}$ & $\begin{array}{l}50 \\
13 \\
10 \\
10 \\
18\end{array}$ & $\begin{array}{r}51 \\
21 \\
7 \\
8 \\
16\end{array}$ & $\begin{array}{r}50 \\
20 \\
7 \\
8 \\
16\end{array}$ & $\begin{array}{l}36 \\
12 \\
12 \\
14 \\
31\end{array}$ & $\begin{array}{l}34 \\
11 \\
11 \\
13 \\
30\end{array}$ \\
\hline$X_{12}$ & $\begin{array}{l}\text { Faith in the joy of life and the sacredness } \\
\text { of death brings with it the hope for eternal life }\end{array}$ & $\begin{array}{l}1 \\
2 \\
3 \\
4 \\
5\end{array}$ & $\begin{array}{r}46 \\
23 \\
71 \\
36 \\
200\end{array}$ & $\begin{array}{r}12 \\
6 \\
19 \\
10 \\
53\end{array}$ & $\begin{array}{r}37 \\
20 \\
60 \\
29 \\
182\end{array}$ & $\begin{array}{r}11 \\
6 \\
18 \\
9 \\
55\end{array}$ & $\begin{array}{r}9 \\
3 \\
11 \\
7 \\
18\end{array}$ & $\begin{array}{r}19 \\
6 \\
23 \\
15 \\
38\end{array}$ & $\begin{array}{l}30 \\
12 \\
30 \\
11 \\
85\end{array}$ & $\begin{array}{r}18 \\
7 \\
18 \\
7 \\
51\end{array}$ & $\begin{array}{r}7 \\
7 \\
17 \\
7 \\
65\end{array}$ & $\begin{array}{r}7 \\
7 \\
17 \\
7 \\
63\end{array}$ & $\begin{array}{r}9 \\
4 \\
24 \\
18 \\
50\end{array}$ & $\begin{array}{r}9 \\
4 \\
23 \\
17 \\
48\end{array}$ \\
\hline
\end{tabular}

MU - Wroclaw Medical University, ULS - University of Lower Silesia, 1 - I strongly disagree with the statement, 2 - I somewhat disagree with the statement, 3 - I have no opinion, 4 - I somewhat agree with the statement, 5 - I strongly agree with the statement

a statistically significant difference between groups 1 and 2

${ }^{b}$ statistically significant difference between groups 2 and 3

${ }^{c}$ statistically significant difference between groups 1 and 3

s statistically significant difference between men and women 
Table 3. Differences between groups of students in responses to statements concerning euthanasia (features $X_{1}-X_{12}$ ) by gender and field of study

\begin{tabular}{|c|l|l|l|l|}
\hline Feature & F-M & $1-2$ & $2-3$ & $3-1$ \\
\hline$X_{1}$ & 0.910 & 0.066 & $0.001^{*}$ & $0.003^{*}$ \\
\hline$X_{2}$ & 0.427 & $0.008^{*}$ & $0.001^{*}$ & $0.004^{*}$ \\
\hline$X_{3}$ & 0.919 & $0.003^{*}$ & 0.414 & $0.031^{*}$ \\
\hline$X_{4}$ & 0.069 & 0.538 & 0.209 & 0.078 \\
\hline$X_{5}$ & $0.008^{*}$ & 0.259 & 0.082 & 0.193 \\
\hline$X_{6}$ & 0.524 & 0.198 & $0.005^{*}$ & $0.019^{*}$ \\
\hline$X_{7}$ & 0.346 & 0.123 & 0.067 & 0.284 \\
\hline$X_{8}$ & 0.476 & 0.249 & $0.001^{*}$ & $0.002^{*}$ \\
\hline$X_{9}$ & 0.765 & $0.001^{*}$ & 0.111 & $0.001^{*}$ \\
\hline$X_{10}$ & 0.194 & 0.215 & 0.120 & $0.026^{*}$ \\
\hline$X_{11}$ & 0.288 & 0.454 & $0.012^{*}$ & 0.082 \\
\hline$X_{12}$ & 0.173 & 0.107 & 0.060 & $0.012^{*}$ \\
\hline
\end{tabular}

$\mathrm{F}$ - females, M - males, 1 - group of physiotherapy students, 2 - group of nursing and midwifery students, 3 - group of education students * statistically significant difference $(p<0.05)$

explained with an additional analysis of the answers to the next statement (feature $X_{7}$ ): 'Focusing on the subject of death lowers one's creative energy'. Here, $64 \%$ of the students disagreed, including $62 \%$ of physiotherapy students, $71 \%$ of nursing and midwifery students, and $59 \%$ of education students, with no statistically significant differences among the groups.

Answers to the statement 'The death of an animal is not different from the death of a human being' (feature $\mathrm{X}_{8}$ ) were the following: $68 \%$ of the respondents disagreed, $13 \%$ had no opinion, and $19 \%$ strongly agreed. A curious case arose in the answers from education students, of whom approximately $59 \%$ disagreed, $18 \%$ had no opinion, and $22 \%$ agreed. Answers from the other 2 groups revealed that approximately $67 \%, 13 \%$, and $21 \%$ of physiotherapy students and $79 \%$, $9 \%$, and $13 \%$ of nursing and midwifery students disagreed, had no opinion, and agreed, respectively. A statistical comparison showed that students of education more often stated that the death of an animal was not different from the death of a human.

Attitudes of the students towards prolonging life of terminally ill people were examined with the statement 'Efforts to prolong the life of terminally ill people have a significant social and economic impact' (feature $\mathrm{X}_{\mathrm{g}}$ ). Although a hospice is an alternative for euthanasia, the students did not see the benefits of hospice care. The research clearly shows that $48 \%$ of the respondents $-57 \%$ of physiotherapy students, $45 \%$ of nursing and midwifery students, and $35 \%$ of education students - thought that helping terminally ill people had negative social and economic impacts. Statistical analysis revealed significant differences among the 3 groups students.

Positive answers to the statement 'Taking care of a terminally ill person has a positive effect on both the sick person and the guardian' (feature $\mathrm{X}_{10}$ ) were given by $70 \%$ of the respondents: $68 \%$ of physiotherapy students, $77 \%$ of nursing and midwifery students, and $69 \%$ of education students. Most of the respondents perceived the positive influence of terminal care on the patients and their caregivers, with no statistically significant differences.

The presence of a difficulty in coping with a dying person, indicated in the statement 'It is hard for me to imagine was more frequent among education students (43\%) than in physiotherapy $(28 \%)$ or nursing and midwifery students (24\%). Statistical analysis revealed differences only between education students and nursing and midwifery students.

Students' belief regarding eternal life is integrally connected with the ideology that they assume in their perception of where life begins and ends. The analysis of the answers to the statement 'Faith in the joy of life and the sacredness of death brings with it the hope for eternal life' (feature $\mathrm{X}_{12}$ ) confirms the belief in life after death in the investigated students' group: positive answers were provided by $70 \%$ of nursing and midwifery students, $65 \%$ of education students, and $58 \%$ of physiotherapy students.

\section{Discussion}

The research indicates that students have a sensitivity for the issue of death, as well as the sacralisation of death, differentiating human death from that of an animal and giving a reason to provide hospice care. Coping with a dying person is an enriching, but also very difficult experience for healthcare workers. Contact with death evokes emotions and shapes certain virtues and attitudes within medical staff, who have gone through proper training to handle it, but it also has an influence on educators [16-20]. In Poland, euthanasia is legally forbidden and considered a crime punishable with 5 years of prison. Despite the law stating it clearly, the analysis of the CBOS Public Opinion Research Center, performed in years 1999, 2001, 2007, and 2009 in a group of 1000 adults chosen randomly to represent the Polish population, indicates that Poles have different opinions on the subject. In the years mentioned above, $42 \%, 48 \%, 37 \%$, and $42 \%$, respectively, of the surveyed group accepted deliberately taking a patient's life away by a physician in terminal disease cases (if this was the patient's wish), while $40 \%, 39 \%, 46 \%$, and $40 \%$, respectively, did not accept this idea [1-4].

Mierzecki et al. [21] reported a tremendous difference in opinions on euthanasia among first-year students of medicine in Szczecin in Poland, Lund in Sweden, and Greifswald in Germany. Euthanasia was acceptable for $48 \%$ of the Polish, $61 \%$ of the Swedish, and $82 \%$ of the German students. 
In a study by Reczek [22], $46 \%$ of the surveyed students of year 2 and 3 of Medical University of Silesia in Katowice, School of Medicine, supported euthanasia.

Leppert et al. [23] conducted a study in Poznan University of Medical Sciences, Department of Dental Medicine. The respondents stated that euthanasia was 'ending terminally ill patients' lives' (12\%) or a 'good death' (5\%), while only being defined as murder by $4 \%$. The other question was: 'If you or someone close to you had a terminal disease, would you prefer to choose natural death, euthanasia, or collaborative suicide?' Most of the respondents (77\%) chose natural death. Euthanasia would be considered an option by $7 \%$ of the doctors and $13 \%$ of the students, while suicide was indicated by $4 \%$ of the doctors and $5 \%$ of the students.

In another research project, Leppert et al. [24] surveyed a group of 263 students of year 6 from Poznan University of Medical Sciences and Medical University of Lodz. Over half of them (56\%) were against euthanasia, while approximately $30 \%$ were hesitant about the question. The remaining $14 \%$ were for euthanasia to lessen the patient's suffering on the patient's request; $35 \%$ of the respondents were for legalizing euthanasia and $49 \%$ were against. Most of those surveyed were afraid of euthanasia abuse if it were legalized.

A study by Matejuk et al. [19] was conducted among randomly selected patients, doctors, medical students, and inhabitants. As it turned out, people under the age of 35 years were the biggest supporters of euthanasia; $75 \%$ of patients, $24.3 \%$ of physicians, and $33 \%$ of students of medicine were against euthanasia. Over half of the respondents (53\%) stated that euthanasia should be forbidden by law and around $1 / 3$ $(31 \%)$ wanted it to be legalized.

In the research undertaken by Mickiewicz et al. [18] with a group of 183 randomly chosen working nurses and students, a large proportion of the respondents (49\%) did not accept euthanasia. A significant section of the research group had no opinion about it, while a definitive acceptance was expressed by $19.7 \%$; only $6 \%$ of nurses would consider euthanasia in very specific conditions and if the patient wished to do so. In the study, $48.9 \%$ of nurses were for artificial support of life and $47.5 \%$ would stop resuscitative actions or disconnect the life-support machines (24\%).

Similar results were obtained by Radulovic and Mojsilovic [20] in their study performed in Belgrade, where only $20 \%$ of students and $30 \%$ of doctors, but $61 \%$ of Serbian lawyers were for euthanasia.

The research by Choińska et al. [25] highlights the fact that euthanasia is more often accepted by young people without health problems or contact with dying people than by people aged 60 years or older. This results from the fact that people perceive youth as the time of health and selfsufficiency. The youth reject the inevitability of old age, as well as death, because suffering, disabilities, and physical limitations oppose the definition of youth itself. Therefore, euthanasia in their opinion gives freedom of choice. We know from the hospice experience that a request for euthanasia is a cry for help, for lessening the pain, and for support. Providing proper treatment, palliative care, and honest talks very often leads to the patient's withdrawal from euthanasia. Well organized palliative care also translates into a decrease of economical costs of care at the end of life [26-32]. CBOS Public Opinion Research Center reports show that the group of euthanasia supporters is growing in the Polish society; in their opinion, law permitting euthanasia should be introduced, enabling physicians to allow terminally ill, suffering patients die faster [3, 4].
This paper can be read by people with different world views, each seeking the truth in their own way. The world outlook is a global interpretation of the whole reality of everything that exists, especially the nature and genesis of man, including man's dying and death. Among the types of world view, the following can be distinguished: hedonistic, aesthetic, ethical-religious, sociological, etc. Individual philosophical, religious, and ideological trends emphasize different types of values: vital-sensual, aesthetic, cognitive-logical, religious, economic, utilitarian, etc. The authors do not conceal their Christian world view but try to present objective truth. The Christian world view focuses on classical values of the truth of goodness, as well as religious and sacred beliefs. Marxism recognizes economic values as fundamental and questions the positive function of brotherly love, instead proposing the ideas of economic equality and social justice obtained through class struggle and revolution. Liberal-individualist world view is the guiding principle of economic values and endorses the priority of freedom over truth. Everyone has to ask themselves which world view and philosophical values they identify with in the face of decisions about unnatural death (euthanasia) and dying [33].

\section{Conclusions}

A precise analysis of the answers to the 12 statements about euthanasia gives grounds for the following conclusions:

1. The attitudes of the students towards euthanasia are, in a great majority, shaped by the curricula of their universities, dependent on their faculty. Physiotherapy students and nursing and midwifery students value human life higher than students of education.

2. Most of the respondents (65\%) state that euthanasia is an act of killing of a human being. Women are more willing to work in a hospice than men, and death penalty is generally considered as suitable legal punishment for the most severe crimes.

3. Overall, $90 \%$ of the students maintain that the subject of death should not be removed from everyday life, and more than a half $(63 \%)$ confesses they believe in life after death. However, a large amount of the education students (43\%) and a quarter of MU students $(25 \%)$ cannot imagine any contact or interaction with a dying person.

\section{Disclosure statement}

No author has any financial interest or received any financial benefit from this research.

\section{Conflict of interest}

The authors state no conflict of interest.

\section{References}

1. CBOS Public Opinion Research Center report. Communication on research BS/134/1999: Attitudes to euthanasia. CBOS: Warsaw; 26.08.1999.

2. CBOS Public Opinion Research Center report. Communication on research BS/93/2007: Opinions about euthanasia i.e. help in dying. CBOS: Warsaw; 12.06.2007.

3. CBOS Public Opinion Research Center report. Communication on research BS/142/2009: Public opinion about euthanasia. CBOS: Warsaw; 20.10.2009.

4. CBOS Public Opinion Research Center report. Communication on research BS/170/2001: Opinions on the legalisation of euthanasia. CBOS: Warsaw; 06.12.2001. 
5. Euthanasia in the world. Where is it legal? [in Polish]. Polityka. 13.02.2014. Available from: https://www.polityka. pl/tygodnikpolityka/swiat/1570593,1,eutanazja-naswiecie--gdzie-jest-legalna.read.

6. Kielanowki T. Ethics and medical deontology [in Polish]. Warszawa: PZWL; 1985.

7. Bołoz W. Rights of a dying man [in Polish]. In: Kośmicki M (ed.), Doctors on euthanasia [in Polish]. Kraków: ITKM; 2002; 116-134.

8. Czachorowski M. Euthanasia [in Polish]. In: Winiarczyk A (ed.), 'White stains' encyclopaedia [in Polish], vol. 5. Radom: PWE; 2001; 313-320.

9. Drążkiewicz J. Towards the dying person. On the hospice movement in Poland [in Polish]. Warszawa: Wyd. Uniwersytetu Warszawskiego; 1989.

10. Ślipko T. Anthropological and ethical bases for terminal care [in Polish]. In: Wojciechowski A (ed.), Situation of a weak man in modern civilisation [in Polish]. Toruń: Wyd. UMK; 1999; 39-46.

11. Nikielski H. Helping the dying [in Polish]. Warszawa: PAX; 1989.

12. Pope John Paul II. Evangelium vitae. Encyclical about the value and inviolability of human life [in Polish]. In: Szczygieł K (ed.), Care for life. Church documents [in Polish]. Tarnów: Biblos; 1998; 41-134.

13. Krąpiec MA, Maryniarczyk A, Jaroszyński P, Zdybicka ZJ. Introduction to philosophy: a guide [in Polish], vol. 1-2. Lublin: Fundacja Servire Veritati, Instytut Edukacji Narodowej; 2000.

14. Jezior J. Methodological problems of application of Likert scale in studies on attitudes to unemployment [in Polish]. Przegl Socjol. 2013;62(1):117-138.

15. Tarka P. Normalization methods of variables and measurement on 5 and 7 point Likert scale [in Polish]. Research Papers of Wrocław University of Economics. 2015; 385:286-295; doi: 10.15611/pn.2015.385.31.

16. Mess E. Challenges in the care of people at the end of life [in Polish]. In: Sawiński K (ed.), Challenges of modern geriatrics and gerontology [in Polish]. Poznań: Wielkopolskie Stowarzyszenie Wolontariuszy Opieki Paliatywnej „Hospicjum Domowe”; 2014; 152-161.

17. Sleziona M, Krzyżanowski D. Attitudes of the nurses in the face of patients' dying and death [in Polish]. Piel Zdr Publ. 2011;1(3):217-223.

18. Mickiewicz I, Krajewska-Kułak E, Kułak W, Lewko J. Attitudes towards euthanasia among health workers, students and family members of patients in hospice in northeastern Poland. Prog Health Sci. 2012;2(1):81-88.

19. Matejuk A, Mikołajczyk E, Lewko A, Abramczyk J, Błasiak T, Rucińska M, et al. Palliative care or euthanasia perception of the issue by patients, doctors, medical students and inhabitants of Podlaskie province [in Polish]. Onkol Pol. 2003;6(1):29-33.

20. Radulovic S, Mojsilovic S. Attitudes of oncologists, family doctor, medical students and lawyers to euthanasia. Support Care Cancer. 1998;6(4):410-415; doi: 10.1007/ s005200050185.

21. Mierzecki A, Rękawek K, Świątowski J, Hoelscher M, Yelva L, Wiśniewska M, et al. Evaluation of attitude towards euthanasia expressed by first year medical students from Szczecin, Greifswald and Lund medical faculties [in Polish]. Ann Acad Med Stetin. 2008;54(1):164169.

22. Reczek L. Medical student of the Medical University of Silesia faced with the issue of euthanasia [in Polish].
23. Leppert W, Łuczak J, Góralski P. Selected problems of palliative care and euthanasia in the opinion of doctors and medical students [in Polish]. Pol Med Paliat. 2005; 4(2):67-76.

24. Leppert W, Gottwald L, Kaźmierczak-Łukaszewicz S. Euthanasia and palliative care problems in the views of sixth-year medical students [in Polish]. Med Paliat. 2009; $1: 45-52$.

25. Choińska AM, Sadowska L, Bartosik B, Filipowski H, Rytwińska W, Pryk A, et al. Opinion research on euthanasia and abortion in students compared to people over 60 years of age in Lower Silesia [in Polish]. Med Paliat. 2015;7(2):130-138.

26. Hermsen MA, ten Have HAMJ. Euthanasia in palliative care journals. J Pain Symptom Manage. 2002;23(6): 517-525; doi: 10.1016/s0885-3924(02)00401-3.

27. Kujawska-Tenner J. Euthanasia and palliative and hospice care [in Polish]. Nowotwory. 1996;46:764-771.

28. Raczyński K. Euthanasia in the opinion of medical and law students [in Polish]. Available from: http://www.racjonalista.pl/kk.php/s,5492/q,Eutanazja.w.opinii.studentow.prawa.i.medycyny.

29. Brodacka M, Choińska AM, Sadowska L, Hama F. Parents of terminally ill children under the care of the Hospice for Children in Wroclaw, with regards to abortion and euthanasia. In: Krzyżanowski D, Krakowiak P, Binnebesel J, Fal AM, Steciwko A (eds.), Live with dignity to the end. Clinical and social aspects of palliative and hospice care, vol. 3. Opole: WCM; 2011: 61-75.

30. Lucchetti G, de Oliveira LR, Leite JR, Lucchetti AL, SBRAME Collaborators. Medical students and controversial ethical issues: results from the multicenter study SBRAME. BMC Med Ethics. 2014;15:85; doi: 10.1186/ 1472-6939-15-85.

31. Youens D, Moorin R. The impact of community-based palliative care on utilization and cost of acute care hospital services in the last year of life. J Palliat Med. 2017; 20(7):736-744; doi: 10.1089/.jpm.2016.0417.

32. Khandelwal N, Brumback LC, Halpern SD, Coe NB, Brumback B, Curtis JR. Evaluating the economic impact of palliative and end-of-life care interventions on intensive care unit utilization and costs from the hospital and healthcare system perspective. J Palliat Med. 2017;20(12):1314-1320; doi: 10.1089/jpm.2016.0548.

33. Kowalczyk S. World view [in Polish]. In: Winiarczyk A (ed.), 'White stains' encyclopaedia [in Polish], vol. 17. Radom: PWE; 2006; 94-95. 